\title{
LEGAL PROTECTION VERSUS LEGAL CONSCIOUSNESS (The changing Perspective in Law and Society Research)
}

\author{
Muhammad Helmy Hakim \\ Fakultas Syariah dan Ekonomi Islam IAIN Antasari Banjarmasin \\ Email: mh.hakim@ymail.com
}

\begin{abstract}
This article discusses the important role of historical, cultural, social, and attitudinal aspects in the study of law, there has been a shift from instrumental law to constitutive law. While instrumental law considers law beyond the social and cultural spheres, constitutive law integrally embraces law, politics, ideology, and action. Legal consciousness is an important asset for marginalised people who are at high risk of discriminative treatments in occupational and social life. Not only will they are legally aware of their rights and obligations at works, they will have adequate knowledge of where and how to name, blame, and claim in case mistreatment do occur. Legally proficient will allow them build legal protection which is not adequately provided by the authorized bodies.
\end{abstract}

Keywords: Instrumental law, Constitutive law, Legal Protection, Legal consciousness.

\section{Introduction}

Nowadays, many countries in the world have established a complex system of laws and institutions expected to protect the interest of people, particularly the marginalised one in the employment sector. This model of legal protection has broader significance in legal theory, it also reflects assumptions in dominant research paradigms in law and society, and even this model and its critique have been applied to other areas of law. ${ }^{1}$

From the legal protection model perspective, the law is authoritative and effective instrument that offers victims with a tool by which they can use to force perpetrators to comply with legal rules. This model adopts that those who have suffered injuries will recognize their harms and invoke the law through litigation. In brief, they assume that those in the protected class are able and convinced to bear these burdens. ${ }^{2}$ This

\footnotetext{
${ }^{1}$ Kristin Bumiller, "Victims in the Shadow of the Law: A Critique of the Model of Legal Protection," Signs 12, no. 3 (1987): 422.

2 Ibid., 106.
} 
kind of strategy is called as "litigious policies," or Complaint-Driven Enforcement $\mathrm{Model}^{4}$, where the enforcement relies on individuals bringing their rights of action. However, strategies of equal protection may inadequately deliver the burdens imposed on marginalised people because they accept the authoritative discourse of law rather than inquiry the compatibility of legal rules with their legal conception.

The proponents of legal consciousness argue that litigation is just one of the many avenues that disputants have in their catalogue of choices. Even though the judiciary is believed to monopolize the enforcement of legal norms, it is not the only source of normative messages in society. Courts are not even the institutions that handle the majority of legal conflicts and neither occupy the center of legal life. To the contrary, only a minimal fraction of disputes that we can label as legal enter the judiciary and from that number is really difficult to know how many are actually resolved. ${ }^{5}$ Thirty years ago, Galanter et.al pointed out that very few cases of dispute were resolved. This minimal resolution was even smaller than the number of cases the court was supposed to deal with, the fraction of which was much smaller than the actual cases of dispute. ${ }^{6}$

As a matter of fact, it is now trite to recapitulate that the modern justice system through aggressive prosecution and legislation of punitive laws against batterers, has failed to respond adequately to crime generally and to marginalised people in particular. ${ }^{7}$ Many research showed that strong legal protection makes a difference, but it also displayed that even in the United States of America where legal protection is strong, some victims are not afforded their rights. ${ }^{8}$

3 Thomas F Burke, Lawyers, Lawsuits, and Legal Rights (Berkeley: University of California Press, 2002), 4.

${ }^{4}$ Human Rights Watch (Organization), Hidden in the Home: Abuse of Domestic Workers with Special Visas in the United States (New York: Human Rights Watch (Organization), 2001), 32.

${ }^{5}$ M. A. Gomez, "All in the Family: The Influence of Social Networks on Dispute Processing (a Case Study of a Developing Economy)," (Stanford University (UMI Number: 3253485) Retrieved August 20, 2009, from Dissertations and Theses database., 2007), 23.

6 Bliss Cartwright, Marc Galanter, and Robert Kidder, "Introduction: Litigation and Dispute Processing," Law \& Society Review 9, no. 1 (1974). Marc Galanter, "Afterword: Explaining Litigation," Law \& Society Review 9, no. 2 (1975). Marc Galanter, "Reading the Landscape of Disputes: What We Know and Don't Know (and Think We Know) About Our Allegedly Contentious and Litigious Society," UCLA Law Review 31, no. 4 (1983). Marc Galanter, "The Day after the Litigation Explosion," Maryland Law Review 46, no. 3 (1986). Marc Galanter, "Adjudication, Litigation and Related Phenomena," in Law and the Social Sciences, ed. L Lipson and S Wheeler(New York: Russel Sage Foundation, 1987).

7 Randy E. Barnett and John III Hagel, Assessing the Criminal. Restitution, Retribution, and the Legal Process (Cambridge: Ballinger Publishing, 1977).

8 The Human Right Watch Report (2001) concluded that The United States has failed to protect migrant domestic workers' rights and to guarantee that workers have an "effective remedy" if their rights are offended. As a matter of fact, the report indicated that there were only six out of twenty-seven domestic workers attempted to file complaints against their employers. Though most of the workers knew that their employment conditions violated U.S. law they did not wish to or did not know how to file legal complaints against their employers see further Human Rights Watch (Organization).. 
However, despite the widespread adoption of legal protection, the implementation of such protection and its impact on victims have not been widely studied. In other words, this kind of research might be considered as the bottomup approach, which is commonly defined in sociology of law literature as the study of critical legal consciousness. This study will provide a brief review of two bodies of research. First, the research reviews the changing perspective of law and society research from an instrumental view of law to the view of law as an integral part of society. This more expansive view of the role of law in society has led to the legal consciousness. Next, it reviews some of the innovative work of legal consciousness scholarship.

\section{Instrumental and Constitutive Perspectives}

There has been a shift the law and society research from instrumental to constitutive perspective. The former treats law as a separated entity and thus autonomous from social life while the latter implies the existence of different competing forces that contribute to shape social life and normative system. Constitutive perspective puts law in the interconnection to and embeddedness in different other fields to allow holistic consideration of law-influencing cultural and social aspects.

Sarat and Kearns ${ }^{9}$ introduced these two different perspectives in this area of research, the instrumental and the constitutive. Although these two perspectives are in similar way in favoring law in studying society, they hold opposing views by which law affects society: whether by imposing external sanctions or by shaping internal meanings. Subsequently, they likely to fail to notice the variety of ways in which society responds to law, occasionally by ignoring it, reconstructing it, or using it in unusual and unanticipated ways.

These two perspectives, the instrumental and constitutive, represent two basic views of the relationship between law and society. Instrumentalist scholarship, which sees law as different from, and acting on society, focuses on legal norms, legal rules, and legal actors. And this separation has been an attempt to make out the power of law as a tool for creating or supporting social change. Instrumentalist tries to "... search for the conditions under which law is effective, that is, when legislation or judicial decisions can be counted on to guide behaviour or produce social changes in desired ways." 10 In short, the instrumentalism emphasizes sharp distinction between legal standards on the one hand, and non-legal human activities, on the other. It then hypothesizes the effectiveness of the legal standard upon society.

On the other view, the constitutive perspective assumes that social life is run through with law, or in other words, "law shapes society from the inside out, by providing the principal categories that make social life seem natural, normal, cohesive, and coherent."'11

\footnotetext{
9 A. Sarat and T. R. Kearns, Law in Everyday Life (Michigan: University of Michigan, 1995).

${ }^{10}$ Ibid., 27.

${ }^{11}$ Ibid., 22.
} 


\section{Scheingold against the instrumentalism}

However Scheingold ${ }^{12}$ argues against the idea of instrumentalism which assume that legal standard with litigation and courts decisions can produce effective social change. He proposes that declaration of rights from courts has been the focus of a great number of law reformers. Effective declaration realizes these rights which lead to equivalently meaningful change. Put in different words, "the myth of rights is directly related to litigation, rights, and remedies with social change."13 The underlying ideology is that "the American political order indeed takes similar patterns of rights and obligations specified in the Constitution."14

Scheingold proposes the legal paradigm which views human interaction largely about rules and rights dominates the ideology of the myth of rights and mischaracterizes the interplay of legal, political and social forces. Surely these views have, at least until lately, dominated the literature on law and politics in the United States. As a matter of fact, Scheingold rejects the myth of rights and proposes the constitutive understanding of law and legal mobilization as he moves from the myth of rights into his discussion of the political significance of the ideology of rights. He puts forward the concept of the politics of rights: "The politics of rights implies a much more comprehensive assessment which includes but transcends the simple straight-line projection from judicial decision to compliance." 15

Scheingold is skeptical of the emphasis on litigation as a tool for redistributing power. He notes the tendency of law and politics to reinforce the status quo, embedded as they are in the existing power structures. Nevertheless, he asserts the ideology of rights can play a significant role in mobilizing action. "The myth of rights provides political ideals [which] influence the behaviour of government and private citizens. The politics of rights is, in short, concerned with the interplay between ideology and action in American politics." 16

It is the recognition of the relationship between law, politics, ideology and action that characterizes the constitutive view of law and society. Sarat and Kearns highlight that constitutive perspective of law decline the instrumentalist picture of law as outside to social practices. They attempt to draw the way legal power and legal forms exist in social relations. Constitutive perspective claim that instrumentalism brings about a falsified impression of the role of law in everyday life. By centering on law as a distinct tool, or efforts of law to change behaviour, instrumentalists diverts attention from the deep, often invisible, but pervasive effects of legal concepts on social practices. ${ }^{17}$

\footnotetext{
${ }^{12}$ Stuart A Scheingold, The Politics of Rights (Michigan: University of Michigan Press, 2007).

${ }^{13}$ Ibid., 5.

${ }^{14}$ Ibid., 17.

${ }^{15}$ Ibid., 8.

${ }^{16}$ Ibid., 83.

${ }^{17}$ Austin Sarat, "The Law Is All Over: Power, Resistance and the Legal Consciousness of the Welfare Poor," Yale Journal of Law and the Humanities 2 (1990): 50.
} 


\section{Bumiller refuses legal protection model}

Bumiller ${ }^{18}$ shows the seeming failure of anti-discrimination doctrine. She contradicts the instrumental concept of law and in the contrary examines the individual attitudes and behaviour which can serve to oppose the apparent goal of civil rights legislation and litigation. She states that the traditional model of legal protection, which supposes law to be a powerful tool to end discriminatory practices, is flawed because it fails to take into account the way individual actions and attitudes are influenced by law. Bumiller takes a firm stand that the view the primacy of the legal order produces the illusion that law is a source of power and authority disconnected from other power structures in society. In fact, the deep logic of the law does not reflect the complex social reality of discrimination in society, but rather restricts legal resolution to social problems appropriate for litigation. ${ }^{19}$

Bumiller argues that the 1964 Act and subsequent legislation generally have failed to rectify earlier forms of injustice, discrimination, and inequality. She notes that the conventional wisdom generally attributes these failures to inadequate resources, entrenched cultural biases, and the slow progress in attaining real economic and social gains. To the contrary, Bumiller says that the model of legal protection that forms the basis for civil rights law itself discourages social victims from emancipating themselves from oppressive conditions. She further argues that protective legislation may serve to perpetuate patterns of behaviour (among both victims and victimizers) that maintain discriminatory practices. Modern law is said to embody and reproduce a socially constructed, dehumanized victim. Bumiller further proposes that there is a current proliferation of antidiscrimination strategies. This proliferation is seen as a coherent extension of the universalization of rights, which is itself a result of the civil rights model of legal protection. She concludes that "by including all groups, it further dilutes the benefits received by the historically most disadvantaged groups." 20

Bumiller refuses the traditional model of legal protection but relies on stories told by victims of discrimination to explore the complications of anti-discrimination law. In order to better understand the relationship between law and social change, she creates a paradigm for legal consciousness research by opposing the perspectives and experiences of individuals against the traditional, instrumentalist view of legal protection. Bumiller's position on the role of law deduces from Foucault's explanation of law and social control. She notes that Foucault's conception of law and ideology moves us away from the conventional view of anti discrimination law as a command directed at its perpetrators to acknowledgement of the law as a form of knowledge and power that shapes its subjects. This brings up the inquiry of how law practices its authority on victims and creates victims views of themselves and their position. ${ }^{21}$

The essential claim of the constitutive approach to the study of law is the assertion that, "Law exercises its power by less obvious means than can be discerned

\footnotetext{
${ }^{18}$ Kristin Bumiller, The Civil Rights Society: The Social Construction of Victims (Baltimore: Johns Hopkins University Press, 1988).

${ }^{19}$ Ibid., 10.

${ }^{20}$ Ibid., 117.

${ }^{21}$ Ibid., 33.
} 
from formal and visible decision making in court." ${ }^{22}$ Bumiller detects evidence of the mutual nature of law as constitutive of social relations and the importance of examining the gap between legal doctrine and law in everyday's life. She affirms the power of legal ideas and concepts to influence social relationships even in the absence of a legal claim. She points out that the introduction of legal themes may shape behaviour at all stages of the conflict - from its creation to its settlement. The situation is metamorphosed by the introduction of law even if the parties do not talk to lawyers or take the case to a legal forum. ${ }^{23}$

The theoretical change from the instrumental view of law to the constitutive view of law leads scholarship toward a acknowledgement of the importance of analysing the ways that law comes out of and is constituted by specific historical, cultural, social situations and attitudes.

The change in the understanding of the meaning of law needs a significant change in the way of the study the relationship between law and society, from a focus on institutions to individuals. Consequently, Bumiller maintains the importance of interviewing individual subjects about their thoughts and experiences with law. "An important premise of this book, therefore, is that neither the potentialities nor the troubles deriving from social conflict can be fully understood outside the changes of an individual life." ${ }^{24}$ Constitutive studies of law have extended to the understanding that law is more than a set of rules and procedures, law constitutes a belief system which is imbedded in, and perpetuates, a certain power structure. It is the study of law as a set of beliefs, and the significances of those beliefs that forms the basis of legal consciousness research.

\section{Discourse of legal consciousness}

Legal consciousness has been an important topic in socio-legal research because it represents the intersection of law as an institutional force and individuals as legal agents. Traditionally, the sociology of law has been related with the legitimacy of law, which finally is rooted in individuals' belief in and adoption of legal order. ${ }^{25}$ However, this traditional conceptualization of legal consciousness which emphasizes on the acceptance of official power by individuals has moved away into the notions of justice and rights that people convey in their minds and practice in their every-day life. Hence, scholars have begun to investigate whether and why people invoke the law in disputes ${ }^{26}$ or in social movements aimed at broader social change. ${ }^{27}$

\footnotetext{
22 Ibid., 37.

${ }^{23}$ Ibid., 36.

${ }^{24}$ Ibid., 35.

${ }^{25}$ Roberto Unger, Law in Modern Society: Toward a Criticism of Social Theory (New York: Free Press, 1985).

${ }^{26}$ Sally Engle Merry, "Anthropology, Law, and Transnational Processes," Annual Review of Anthropology 21, no. (1992).

${ }^{27}$ Michael McCann, Rights at Work (Chicago: University of Chicago Press, 1994).
} 
Merry $^{28}$ defines consciousness as "people's conception of the "natural" and normal method of work acccomplishment, habitual patterns of talk and action, and commonsense in understanding of the world." Further she asserts that consciousness is not only the realm of "deliberate, intentional action but also that of habitual action and practice." ${ }^{29}$ In line to Merry, Ewick \& Silbey define consciousness as the part of a reciprocal process through the patterned, stabilized, and objectified meanings given by individuals to their world. The already institutionalized meaning becomes part of the material and discursive systems to limit and constrain the making of new meanings in future time. ${ }^{30}$ Nielsen puts that their commonsense understanding of the way law works. ${ }^{31}$ In other words, legal consciousness refers to the way people think about the law. This includes the prevailing norms, day-by-day practices, and commonly adopted ways of legal problem solving. Put differently, this results from legally- and ideologically-related experiences. ${ }^{32}$

In relation to consciousness, Max Weber introduced "the subjective meaningcomplex of action" ${ }^{33}$ which can be implemented to the intersection of social agency and legal consciousness. Opposed to Marx, Weber proposes that culture can influence agency while agency can influence culture. Weber describes the subjective interpretation of action as an effect to understand human behaviour in terms of "the concepts of collective entities." 34 This suggests that for Weber a dual character of action/consciousness in which thoughts or concepts "have a meaning in the minds of individual persons, partly as of something actually existing, partly as something with normative authority." 35

Consciousness is subjective, the product of an interaction between the observer and the observed. ${ }^{36}$ Jean Comaroff defines consciousness as "inherent in the daily-life practical constitution and is integrated in the process in which external social and cultural factors have constituted the subject. ${ }^{137}$ Consciousness may appear in subtle and different ways of how people act and speak and what their utterance contain. ${ }^{38}$ This becomes an integrated part of practical knowledge to which people refer when

${ }^{28}$ Sally Engle Merry, Getting Justice and Getting Even: Legal Consciousness among Working-Class Americans, Language and Legal Discourse (Chicago: University of Chicago Press, 1990).

${ }^{29}$ Ibid., 5.

${ }^{30}$ Patricia Ewick and Susan S. Silbey, The Common Place of Law: Stories from Everyday Life, Language and Legal Discourse (Chicago: University of Chicago Press, 1998), 39.

${ }^{31}$ Laura Beth Nielsen, License to Harass: Law, Hierarchy, and Offensive Public Speech (Princeton: Princeton University Press, 2004).

${ }^{32}$ Ibid., 7.

${ }^{33}$ Max Weber, The Theory of Social and Economic Organization (New York: Oxford University Press, 1947), 102.

${ }^{34}$ Ibid.

${ }^{35}$ Ibid., 101-102.

${ }^{36}$ Merry, Getting Justice and Getting Even: Legal Consciousness among Working-Class Americans, 4.

${ }^{37}$ J. Comaroff, Body of Power: Spirit of Resistance: Culture and History of a South African People (Chicago: Univ. Chicago Press, 1985), 5.

${ }^{38}$ J. Comaroff and J. L. Comaroff, Of Revelation and Revolution: Christianity, Colonialism, and Consciousness in South Africa, vol. 1 (Chicago: Univ. Chicago Press, 1991). 
doing things. The construct of consciousness is much more dynamic than a mere social entity. This "type of social practice" 39 assigns meanings to social structures, which is not an end. The assigned meaning will undergo further refinement, reproduction, and development along individual experience that occurs within the social structures by which one's live is defined. Of equal importance, it changes with contradictory experiences. People question what they are doing and shift directions if it appears that their way of acting either is not working or contradicts what happens to them. ${ }^{40}$

Time has played an important role in the process of individual's consciousness changes. One's consciousness is likely to change along with their experience in social process. Such this change in consciousness constitutes a great interaction of social and structural entities. Comprehension about how consciousness changes will help a systematic discussion of legal consciousness. Nielsen asserts that consciousness, is simultaneously created and communicated; it is contingent, meaning that it changes based on the knowledge and experiences of individuals, as well as context. ${ }^{41}$

Legal consciousness refers to "how people understand and use the law" and "participate in legality construction process." ${ }^{42}$ Recently many legal consciousness studies have merely emphasized on law conceptualization and its impacts on the individuals' daily lives. ${ }^{43}$ They reveal the dynamic nature of legal consciousness concept. It is not the external enforcement that counts in legal consciousness establishment, but rather, it is internally learned process through which individuals gain their legal consciousness. They are in active engagement to form their individual specific legal consciousness. First, social consciousness becomes the foundation of individual legal consciousness. Second, with legal experiences and reactions they develop their legal consciousness. The dynamic nature of legal consciousness construct and its socially related process are manifested in words or actions, a multifaceted, contradictory, and variable legal consciousness." ${ }^{44}$

Establishment of legal consciousness does not stand alone. Different aspects play a role in the establishment of legal consciousness. They are, among others, the perceptions of lawmaking bodies, the court system, law enforcement and other "meanings, sources of authority, and cultural practices commonly recognized as legal." ${ }^{45}$ As it is common in other schemas, legality is not exclusively inherent in individual's ideas and attitudes. To be always vital, individuals and groups have to

${ }^{39}$ Ewick and Silbey, 225.

${ }^{40}$ Merry, Getting Justice and Getting Even: Legal Consciousness among Working-Class Americans, 5.

${ }^{41}$ Laura Beth Nielsen, "License to Harass: Offensive Public Speech, Legal Consciousness, and Hierarchies of Race, Gender and Class," (University of California, Berkeley (UMI Number: 9931344) Retrieved August 21, 2009, from Dissertations and Theses database, 1999), 39.

${ }^{42}$ Ewick and Silbey, 35; Merry, Getting Justice and Getting Even: Legal Consciousness among Working-Class Americans.

${ }^{43}$ Erik W. Larson, "Institutionalizing Legal Consciousness: Regulation and the Embedding of Market Participants in the Securities Industry in Ghana and Fiji " Law \& Society Review 38, no. 4 (2004).

${ }^{44}$ Susan S. Silbey, "Making a Place for Cultural Analyses of Law," Law \& Social Inquiry 17, no. 1 (1992): 46.

${ }^{45}$ Ewick and Silbey, 22. 
continually produce, work, invoke, and deploy it." ${ }^{46}$ As suggested by some legal consciousness studies, legal ideas may be pushed and pulled, which implies the texture of law in our everyday existence in order to construct legality. ${ }^{47}$

Law may be pulled to construct and restrict what people may act and decide. The restriction is elaborated into the elaborated regulations, conduct-prohibition codes, and social norms. They are all designed to reserve the already arranged power and order. Through their familiarity these codes, lay people will be used to adopting $\mathrm{t}$ and obeying the formal regulations. Such this acceptance by the people has opened a way for the law to shape the everyday life of the people and rule some courses of action without which they would have been taken otherwise. In this way, law has created natural, normal, cohesive, and coherent society based on the principal categories." 48

At the same time, law may be pushed by individuals' own readings of law." This kind of process has enriched the variants of legality. In this perspective, law indeed dynamically develops. Through legality context in daily life, ordinary people contribute to shape and assign meaning to an "abstract but binding form." 49 The legality enacted everyday in turn, will result in the establishment of a theory for legal, institutional, and social changes. Any decision that may have impacts on the law will result in new meaning and a new legal claim. Therefore, while it restricts what action individuals may have taken, opportunities of redefinition of and challenge against the restraints are wide open. ${ }^{50}$ With legality, individuals may also anticipate on the vast resources of the state by mobilizing the law. The accumulated of individual's needs for legal system is likely to result in great effects on other people through the creation of new legal rights and novel legal claims. ${ }^{51}$ Thus, in spite of the fact that law has colonized everyday existence through oppression and inequality, legality provides a means of resistance. ${ }^{52}$ Legal consciousness studies have revealed that the law provides schemas and frames to construct the meaning of what people have experienced. ${ }^{53}$ Using the existing legal concepts and resources, people assign meaning to their disputes with their neighbors, their family problems, even their experiences with street harassment. ${ }^{54}$ ${ }^{46}$ Ibid., 43.

${ }^{47}$ Anna Maria Marshall and S. Barclay, "In Their Own Words: How Ordinary People Construct the Legal World," Law \& Social Inquiry 28, no. 3 (2003a): 617.

${ }^{48}$ Sarat and Kearns, Law in Everyday Life, 22.

${ }^{49}$ Marshall and Barclay.

${ }^{50}$ Ewick and Silbey.

${ }^{51}$ Frances Zemans, "Legal Mobilization: The Neglected Role of the Law in the Political System," APSR 77, no. (1983).

${ }^{52}$ Michael McCann and Tracey March, "Law and Everyday Forms of Resistance: A Socio-Political Assessment," Studies in Law Politics and Society 15, no. (1995); Sally Engle Merry, "Culture, Power, and the Discourse of Law," New York Law School Law Review 37, no. (1995a); Sally Engle Merry, "Resistance and the Cultural Power of Law " Law \& Society Review 29, no. 1 (1995b); Sarat and Kearns, Law in Everyday Life.

${ }^{53}$ Patricia Ewick and Susan S. Silbey, "Conformity, Contestation, and Resistance: An Account of Legal Consciousness., Vol. 26/731," New England Law Review 26, no. (1992); Merry, Getting Justice and Getting Even: Legal Consciousness among Working-Class Americans.

${ }^{54}$ Merry, Getting Justice and Getting Even: Legal Consciousness among Working-Class Americans; Laura Beth Nielsen, "Situating Legal Consciousness: Experiences and Attitudes of Ordinary Citizens 
Studies of legal consciousness deals with "how, where, and with what effect law is produced in and through commonplace social interactions within neighborhoods, workplaces, families, schools, community organizations and the like." 55

\section{Concluding Remark}

Considering the important role of historical, cultural, social, and attitudinal aspects in the study of law, there has been a shift from instrumental law to constitutive law. While instrumental law considers law beyond the social and cultural spheres, constitutive law integrally embraces law, politics, ideology, and action.

Legal consciousness is an important asset for marginalised people who are at high risk of discriminative treatments in occupational and social life. Not only will they are legally aware of their rights and obligations at works, they will have adequate knowledge of where and how to name, blame, and claim in case mistreatment do occur. Legally proficient will allow them build legal protection which is not adequately provided by the authorized bodies.

\section{Reference List}

Barnett, Randy E., and John III Hagel. Assessing the Criminal. Restitution, Retribution, and the Legal Process. Cambridge: Ballinger Publishing, 1977.

Bumiller, Kristin. "Victims in the Shadow of the Law: A Critique of the Model of Legal Protection." Signs 12, no. 3 (1987): 421-439.

Bumiller, Kristin. The Civil Rights Society: The Social Construction of Victims. Baltimore: Johns Hopkins University Press, 1988.

Burke, Thomas F. Lawyers, Lawsuits, and Legal Rights. Berkeley: University of California Press, 2002.

Cartwright, Bliss, Marc Galanter, and Robert Kidder. "Introduction: Litigation and Dispute Processing." Law \& Society Review 9, no. 1 (1974): 5-8.

Comaroff, J. Body of Power: Spirit of Resistance: Culture and History of a South African People. Chicago: Univ. Chicago Press, 1985.

Comaroff, J., and J. L. Comaroff. Of Revelation and Revolution: Christianity, Colonialism, and Consciousness in South Africa. Vol. 1. Chicago: Univ. Chicago Press, 1991.

Ewick, Patricia , and Susan S. Silbey. "Conformity, Contestation, and Resistance: An Account of Legal Consciousness. , Vol. 26/731." New England Law Review 26 (1992): 731-749.

Ewick, Patricia , and Susan S. Silbey. The Common Place of Law: Stories from Everyday Life Language and Legal Discourse. Chicago: University of Chicago Press, 1998.

Galanter, Marc. "Why the Haves" Come out Ahead: Speculations on the Limits of Legal Change.” Law \& Society Review 9, no. 95-127 (1974).

Galanter, Marc. "Afterword: Explaining Litigation." Law \& Society Review 9, no. 2 (1975): 347-368

About Law and Street Harassment," Law \& Society Review 34, no. 4 (2000).

55 Ewick and Silbey, The Common Place of Law: Stories from Everyday Life, 20. 
Galanter, Marc. "Reading the Landscape of Disputes: What We Know and Don't Know (and Think We Know) About Our Allegedly Contentious and Litigious Society." UCLA Law Review 31, no. 4 (1983): 7-71.

Galanter, Marc. "The Day after the Litigation Explosion." Maryland Law Review 46, no. 3 (1986): 3-39.

Galanter, Marc. "Adjudication, Litigation and Related Phenomena." In Law and the Social Sciences, edited by L Lipson and S Wheeler, 151-257. New York: Russel Sage Foundation, 1987.

Gomez, M. A. "All in the Family: The Influence of Social Networks on Dispute Processing (a Case Study of a Developing Economy)." Stanford University (UMI Number: 3253485) Retrieved August 20, 2009, from Dissertations and Theses database., 2007.

Human Rights Watch (Organization). Hidden in the Home: Abuse of Domestic Workers with Special Visas in the United States. New York: Human Rights Watch (Organization), 2001.

Larson, Erik W. . "Institutionalizing Legal Consciousness: Regulation and the Embedding of Market Participants in the Securities Industry in Ghana and Fiji " Law \& Society Review 38, no. 4 (2004): 737-768.

Marshall, Anna Maria, and S. Barclay. "In Their Own Words: How Ordinary People Construct the Legal World." Law \& Social Inquiry 28, no. 3 (2003a): 617-628.

McCann, Michael. Rights at Work. Chicago: University of Chicago Press, 1994.

McCann, Michael, and Tracey March. "Law and Everyday Forms of Resistance: A Socio-Political Assessment." Studies in Law Politics and Society 15 (1995): 207-236.

Merry, Sally Engle. Getting Justice and Getting Even: Legal Consciousness among Working-Class Americans Language and Legal Discourse. Chicago: University of Chicago Press, 1990.

Merry, Sally Engle. "Anthropology, Law, and Transnational Processes." Annual Review of Anthropology 21 (1992): 357-379.

Merry, Sally Engle. "Culture, Power, and the Discourse of Law." New York Law School Law Review 37 (1995a): 209-225.

Merry, Sally Engle. "Resistance and the Cultural Power of Law " Law \& Society Review 29, no. 1 (1995b): 11-26.

Nielsen, Laura Beth. "License to Harass: Offensive Public Speech, Legal Consciousness, and Hierarchies of Race, Gender and Class." University of California, Berkeley (UMI Number: 9931344) Retrieved August 21, 2009, from Dissertations and Theses database, 1999.

Nielsen, Laura Beth. "Situating Legal Consciousness: Experiences and Attitudes of Ordinary Citizens About Law and Street Harassment." Law \& Society Review 34, no. 4 (2000): 1055-1090. 
Nielsen, Laura Beth. License to Harass: Law, Hierarchy, and Offensive Public Speech. Princeton: Princeton University Press, 2004.

Sarat, A., and T. R. Kearns. Law in Everyday Life. Michigan: University of Michigan, 1995.

Sarat, Austin. "The Law Is All Over: Power, Resistance and the Legal Consciousness of the Welfare Poor." Yale Journal of Law and the Humanities, no. 2 (1990): 343-379.

Scheingold, Stuart A. The Politics of Rights. Michigan: University of Michigan Press, 2007.

Silbey, Susan S. "Making a Place for Cultural Analyses of Law." Law \& Social Inquiry 17, no. 1 (1992): 39-48.

Unger, Roberto. Law in Modern Society: Toward a Criticism of Social Theory. New York: Free Press, 1985.

Weber, Max. The Theory of Social and Economic Organization. New York: Oxford University Press, 1947.

Zemans, Frances. "Legal Mobilization: The Neglected Role of the Law in the Political System." APSR 77 (1983): 690-703. 